\title{
Reduction of Muscarinic Receptor Density and of Guanine Nucleotide-Stimulated Phosphoinositide Hydrolysis in Human SH-SY5Y Neuroblastoma Cells Following Long- Term Treatment with 12-O-Tetradecanoylphorbol 13-Acetate or Mezerein
}

\author{
Catherine L. Cioffi and *Stephen K. Fisher \\ Neuroscience Laboratory and ${ }^{*}$ Department of Pharmacology, University of Michigan, Ann Arbor, Michigan, U.S.A.
}

\begin{abstract}
The actions of tumor promoters on the coupling of muscarinic receptors to the hydrolysis of inositol lipids and the generation of $\mathrm{Ca}^{2+}$ signals were examined in the human neuroblastoma SH-SY 5 Y cell line. Pretreatment of SHSY5Y cells with $50 \mathrm{n} M$ 12-O-tetradecanoylphorbol 13-acetate (TPA) for 5 days resulted in neuronal differentiation, a $28 \%$ decrease in both $N-\left[{ }^{3} \mathrm{H}\right]$ methylscopolamine and $\left[{ }^{3} \mathrm{H}\right]$ scopolamine binding, and a significantly larger reduction $(48 \%)$ in agonist-stimulated ${ }^{3} \mathrm{H}$-inositol phosphate generation. Whereas mezerein could mimic the effects produced by TPA, the biologically inactive $4 \alpha$-phorbol 12,13-didecanoate was without effect on both antagonist binding and agonist-stimulated phosphoinositide (PPI) turnover. A decline ( 50\%) in the agonist-mediated rise in cytoplasmic $\mathrm{Ca}^{2+}$ and a substantial loss of protein kinase $\mathrm{C}$ activity also were observed following pretreatment with TPA or mezerein. The ability of fluoride, an agent capable of direct activation of guanine nucleotide binding proteins, to stimulate ${ }^{3} \mathrm{H}$-inositol phosphate release was significantly reduced in SH-SY5Y cells treated with these agents. Furthermore, pretreatment of SHSY5Y neuroblastoma cells with TPA or mezerein impaired
\end{abstract}

${ }^{3} \mathrm{H}$-inositol phosphate formation induced by the addition of either guanosine 5'-O-(3-thiotriphosphate) or carbamylcholine to digitonin-permeabilized cells, but not that elicited by the addition of $2 \mathrm{mM} \mathrm{CaCl}$. Although cells cultured in the presence of serum-free media also exhibited neuronal differentiation, no significant alteration in either muscarinic receptor number or agonist-stimulated PPI hydrolysis was observed. The results suggest that TPA and mezerein decrease agonist-stimulated PPI hydrolysis and $\mathrm{Ca}^{2+}$ signaling in $\mathrm{SH}$ SY5Y cells not only by a reduction in muscarinic receptor number but also through an inhibition of guanine nucleotidestimulated PPI turnover. Key Words: Phosphoinositide-Human neuroblastoma-SH-SY5Y-Muscarinic receptorMezerein-12-O-Tetradecanoylphorbol 13-acetate. Cioffi C. L. and Fisher S. K. Reduction of muscarinic receptor density and of guanine nucleotide-stimulated phosphoinositide hydrolysis in human SH-SY5Y neuroblastoma cells following long-term treatment with 12-O-tetradecanoylphorbol 13-acetate or mezerein. $J$. Neurochem. 54, 17251734 (1990).
Human neural tumor cells, such as the SH-SY5Y neuroblastoma clone, can differentiate morphologically upon prolonged exposure to low concentrations of the biologically active phorbol ester, 12-O-tetradecanoylphorbol 13-acetate (TPA), an activator of protein kinase C (PKC) (Akerman et al., 1984; Nishizuka, 1984;
Adem et al., 1987; Heikkila et al., 1987). This neuronal differentiation is associated with neurite outgrowth (Pahlman et al., 1981, 1984), electrical excitability (Akerman et al., 1984), increases in neurotransmitter levels, and neurosecretory granules (Pahlman et al., 1981). Although the effects of phorbol esters on differ-
Received May 17, 1989; revised manuscript received September 5, 1989; accepted October 11,1989

Address correspondence and reprint requests to Dr. S. K. Fisher at Neuroscience Laboratory, University of Michigan, $1103 \mathrm{E}$. Huron Street, Ann Arbor, MI 48104-1687, U.S.A.

Abbreviations used: $\left[\mathrm{Ca}^{2+}\right]_{\mathrm{i}}$, concentration of cytoplasmic $\mathrm{Ca}^{2+}$; DMEM, Dulbecco's modified Eagle's medium; FBS, fetal bovine serum; fura-2/AM, 1-[2-(5-carboxyoxazol-2-yl)-6-aminobenzofuran5-oxy]-2-2(2'-amino-5'-methylphenoxy)-n-ethane- $N, N, N^{\prime}, N^{\prime}$-tetra- acetic acid (pentaacetoxymethyl ester); $G_{p}$, guanine nucleotide protein that regulates phosphoinositide hydrolysis; GTP $\gamma \mathrm{S}$, guanosine $5^{\prime}-O$ (3-thiotriphosphate); $\left[{ }^{3} \mathrm{H}\right] \mathrm{NMS}, \quad N-\left[{ }^{3} \mathrm{H}\right]$ methylscopolamine; $\left[{ }^{3} \mathrm{H}\right] \mathrm{PBCM}$, [propyl-2,3- ${ }^{3} \mathrm{H}$ ] benzilylcholine mustard; $4 \alpha$-PDD, $4 \alpha-$ phorbol 12,13-didecanoate; PKC, protein kinase C; PPI, phosphoinositide (phosphatidylinositol, phosphatidylinositol 4-phosphate, and phosphatidylinositol 4,5-bisphosphate); TCA, trichloroacetic acid; TPA, 12-O-tetradecanoylphorbol 13-acetate. 
entiation have been well documented, little is known of possible alterations in signal transduction mechanisms under these conditions. SH-SY5Y neuroblastoma cells express muscarinic acetylcholine receptors (Adem et al., 1987; Serra et al., 1988; Lambert et al., 1989), which are coupled to breakdown of inositol lipids (Serra et al., 1988; Fowler et al., 1989). Previous reports have demonstrated that chronic TPA treatment induces a down-regulation of muscarinic receptor number in this neuronal clone (Adem et al., 1987; Heikkila et al., 1987). In the present study, we have utilized SH-SY5Y cells to examine the coupling of muscarinic receptors to the hydrolysis of inositol lipids and $\mathrm{Ca}^{2+}$ signaling following differentiation by means of either TPA or mezerein, or, alternatively, by deprivation of fetal calf serum. The results indicate that whereas long-term treatment of SH-SY5Y cells with either TPA or mezerein elicits a reduction in muscarinic receptor number, an even more pronounced inhibition of agonist-stimulated inositol phosphate generation and of $\mathrm{Ca}^{2+}$ mobilization occurs. Furthermore, using either intact cells stimulated with fluoride or digitonin-permeabilized cells stimulated with guanosine 5'-O-(3-thiotriphosphate) (GTP $\gamma \mathrm{S})$, we demonstrate that the effects of TPA and mezerein on inositol lipid turnover result not only from a loss of muscarinic receptors, but also from an inhibition of the guanine nucleotide binding protein $\left(G_{p}\right)$ that regulates phosphoinositide (PPI) hydrolysis in these cells. In contrast with the effects observed for tumor promoters, no significant changes in either muscarinic receptor density or agonist-stimulated PPI hydrolysis occurred when differentiation was induced by culturing SH-SY5Y cells in serum-free media.

\section{MATERIALS AND METHODS}

myo-[2- $\left.{ }^{3} \mathrm{H}\right]$ Inositol $(15 \mathrm{Ci} / \mathrm{mmol})$ was obtained from American Radiolabeled Chemicals (St. Louis, MO, U.S.A.). $\left[\gamma_{-}{ }^{32} \mathrm{P}\right] \mathrm{ATP}(5,000 \mathrm{Ci} / \mathrm{mmol})$ was purchased from Amersham Corporation (Chicago, IL, U.S.A.). $N-\left[{ }^{3} \mathrm{H}\right]$ Methylscopolamine $\left(\left[{ }^{3} \mathrm{H}\right] \mathrm{NMS} ; 73.8 \mathrm{Ci} / \mathrm{mmol}\right)$ and $\left[\right.$ propyl $\left.-2,3-{ }^{3} \mathrm{H}\right]-$ benzilylcholine mustard $\left(\left[{ }^{3} \mathrm{H}\right] \mathrm{PBCM} ; 52 \mathrm{Ci} / \mathrm{mmol}\right)$ were from New England Nuclear (Boston, MA, U.S.A.). $\left[{ }^{3} \mathbf{H}\right]-$ Scopolamine $(75 \mathrm{Ci} / \mathrm{mmol})$ was custom synthesized by Amersham Corp. Dowex AG1-X8 (100-200 mesh, formate form) and Bio-Rad Protein Assay were obtained from BioRad Labs (Rockville Center, NY, U.S.A.). Pirenzepine was obtained from Boehringer-Ingelheim (Ridgefield, CT, U.S.A.). GTP $\gamma \mathrm{S}$ was purchased from Boehringer-Mannheim (Indianapolis, IN, U.S.A.). Carbamylcholine, digitonin, HEPES, mezerein, $4 \alpha$-phorbol 12,13-didecanoate ( $4 \alpha$-PDD), TPA, phenylmethylsulfonyl fluoride, dithiothreitol, histone III-S, phosphatidylserine, Triton X-100, 1,2-diolein, and leupeptin were obtained from Sigma Chemical Co. (St. Louis, MO, U.S.A.). Diethylaminoethyl (DEAE)-Sephacel was from Pharmacia Biotechnology (Gaithersburg, MD, U.S.A.). Tissue culture supplies were obtained from Corning Glass Works (Corning, NY, U.S.A.). Powdered Dulbecco's modified Eagle's medium (DMEM) and fetal bovine serum (FBS) were purchased from Grand Island Biological Co. (Grand Island,
NY, U.S.A.). The SH-SY5Y cell line was kindly provided by Dr. June L. Biedler of the Sloan-Kettering Institute for Cancer Research (Rye, NY, U.S.A.).

\section{Cell culture conditions}

Human SH-SY5Y neuroblastoma cells (passage 65-80) were grown in tissue culture flasks $\left(75 \mathrm{~cm}^{2} / 250 \mathrm{ml}\right)$ in $20 \mathrm{ml}$ of DMEM with high glucose supplemented with $10 \%$ (vol/ vol) FBS. The cells were incubated at $37^{\circ} \mathrm{C}$ in an atmosphere consisting of $10 \% \mathrm{CO}_{2}$ and $90 \%$ humidified air. Confluent cells grown for 10-20 days were subcultured by incubation in a modified Puck's $D_{1}$ solution (Honegger and Richelson, 1976). The cells were collected by centrifugation ( $300 \mathrm{~g}$ for $1 \mathrm{~min}$ ), resuspended into DMEM, and redistributed into culture flasks. The culture medium was changed on day 5 and on alternate days thereafter by the addition of $10 \mathrm{ml}$ of fresh DMEM and removal of $10 \mathrm{ml}$ of medium.

\section{Differentiation}

Confluent cells were subcultured in tissue culture flasks $\left(75 \mathrm{~cm}^{2} / 250 \mathrm{ml}\right.$ ) in DMEM with $10 \%$ FBS in the absence or presence of TPA $(50 \mathrm{n} M)$ or mezerein $(100 \mathrm{n} M)$. Stock solutions were prepared in absolute ethanol and were always introduced to newly passaged cells; the same ethanol concentration was present in the control cells. All experiments were performed with 80-90\% confluent cultures on day 5 following subculture. For differentiation in the absence of fetal calf serum, cells were grown in the presence of DMEM alone for 6-7 days. Intact cells were harvested for assay as described above. The cell pellet was resuspended in HEPES physiological salt buffer solution (142 $\mathrm{m} M$ NaCl, $5.6 \mathrm{~m} M$ $\mathrm{KCl}, 2.2 \mathrm{~m} M \mathrm{CaCl}_{2}, 3.6 \mathrm{~m} M \mathrm{NaHCO}_{3}, 1 \mathrm{~m} M \mathrm{MgCl}_{2}, 5.6$ $\mathrm{m} M$ D-glucose, and $30 \mathrm{~m} M \mathrm{Na}^{+}$HEPES; $\mathrm{pH}$ 7.4).

\section{Electrophoresis of labeled muscarinic receptors}

Intact SH-SY5Y cells were labeled with $\left[{ }^{3} \mathrm{H}\right] \mathrm{PBCM}$, analyzed by sodium dodecyl sulfate-urea gel electrophoresis and visualized autoradiographically as described previously (Fisher and Heacock, 1988).

\section{Radioligand binding assays}

The binding of $\left[{ }^{3} \mathrm{H}\right] \mathrm{NMS}$ and $\left[{ }^{3} \mathrm{H}\right]$ scopolamine to muscarinic receptors on intact SH-SY5Y cells was measured as previously described (Fisher, 1988).

\section{Assay for release of labeled inositol phosphates}

Intact cells. SH-SY5Y cells were harvested as described above, resuspended in HEPES buffer containing $\left[{ }^{3} \mathrm{H}\right]$ inositol $(\sim 10 \mu \mathrm{Ci} / \mathrm{ml})$ at a protein concentration of $1 \mathrm{mg} / \mathrm{ml}$, and allowed to prelabel for $60 \mathrm{~min}$ at $37^{\circ} \mathrm{C}$. After $55 \mathrm{~min}$, lithium chloride was added to achieve a final concentration of 10 $\mathrm{m} M$. The reaction was initiated by the addition of $50 \mu \mathrm{l}$ of carbamylcholine or buffer to assay tubes containing 450- $\mu \mathrm{l}$ aliquots of labeled cells followed by a 60 -min incubation at $37^{\circ} \mathrm{C}$. When fluoride was used as an activator, intact cells were allowed to prelabel overnight with $5 \mu \mathrm{Ci} / \mathrm{ml}\left[{ }^{3} \mathrm{H}\right]$ inositol. A 50- $\mu$ l aliquot of $\mathrm{NaF}$ was added to assay tubes containing $450 \mu \mathrm{l}$ of labeled cells and incubated for $20 \mathrm{~min}$ at $37^{\circ} \mathrm{C}$. (A 20 -min incubation was chosen due to the lack of linearity of $\mathrm{NaF}$-stimulated ${ }^{3} \mathrm{H}$-inositol phosphate formation with further incubation.) The reaction was terminated by addition of $1.5 \mathrm{ml}$ of chloroform/methanol $(1: 2, \mathrm{vol} / \mathrm{vol})$, and the total water soluble inositol phosphate fraction was scparated and quantitated by ion-exchange chromatography (Fisher and Snider, 1987). The majority of the radiolabel recovered was in inositol monophosphate $(63 \%)$, with the remainder in 
glycerophosphorylinositol (34\%), inositol bisphosphate (2.3\%), inositol trisphosphate $(0.4 \%)$, and inositol tetrakisphosphate $(0.3 \%)$. The ratios of ${ }^{3} \mathrm{H}$-inositol phosphates remained unchanged following TPA treatment. Basal levels of ${ }^{3} \mathrm{H}$-inositol phosphate release were subtracted from all carbamylcholine- and NaF-stimulated values. In all experiments, a $200-\mu 1$ aliquot was removed from the organic phase to determine the incorporation of $\left[{ }^{3} \mathrm{H}\right]$ inositol into the phospholipid fraction (Fisher and Bartus, 1985).

Permeabilized cells. The release of inositol phosphates from digitonin-permeabilized cells was measured as described previously (Fisher et al., 1989).

Measurement of cytoplasmic calcium concentration

Cytoplasmic $\mathrm{Ca}^{2+}$ concentrations $\left(\left[\mathrm{Ca}^{2+}\right]_{\mathrm{i}}\right)$ were determined by the use of the fluorescent $\mathrm{Ca}^{2+}$ indicator, fura-2, as previously described (Fisher et al., 1989). Single-wavelength fluorescence was routinely monitored using a Shimadzu RF5000 spectrofluorophotometer. In some experiments, $\left[\mathrm{Ca}^{2+}\right]_{\mathrm{i}}$ in fura-2/AM-loaded cells was determined by the dual-wavelength method of Grynkiewicz et al. (1985) by manual switching of the excitation wavelengths. Both methods yielded similar results.

\section{PKC assay}

Intact SH-SY5Y cells were harvested as described above and homogenized at $4^{\circ} \mathrm{C}$ in three volumes of homogenization buffer (20 m $M$ Tris-HCl, pH 7.5, $1 \mathrm{~m} M$ EGTA, $1 \mathrm{~m} M$ EDTA, $2 \mathrm{~m} M$ dithiothreitol, $250 \mathrm{~m} M$ sucrose) plus $1 \mathrm{~m} M$ phenylmethylsulfonyl fluoride, $50 \mu \mathrm{g} / \mathrm{ml}$ leupeptin, and $1 \mu \mathrm{g} / \mathrm{ml}$ pepstatin A using a Brinkmann Polytron (setting 7, three 5$\mathrm{s}$ bursts). The homogenate was centrifuged at $100,000 \mathrm{~g}$ for $60 \mathrm{~min}$ at $4^{\circ} \mathrm{C}$. The resultant supernatant fluid was collected and is referred to as the cytosolic fraction. To solubilize any PKC activity tightly associated with the membrane, the membrane pellet was resuspended in Tris homogenization buffer containing $0.1 \%$ Triton $\mathrm{X}-100$ and extracted on ice for $45 \mathrm{~min}$. Following centrifugation at $100,000 \mathrm{~g}$ for $60 \mathrm{~min}$ at $4^{\circ} \mathrm{C}$, the supernatant fluid was collected to obtain the membrane fraction. The resultant cytosolic and membrane fractions were loaded onto DEAE-Sephacel columns $(1-\mathrm{ml}$ bed volume) previously equilibrated with homogenization buffer. The columns were washed with five volumes of the same buffer, and PKC was eluted with $100 \mathrm{~m} M \mathrm{NaCl}$ in homogenization buffer. PKC activity was determined by measuring the transfer of ${ }^{32} \mathbf{P}$ from $\left[\gamma-{ }^{32} \mathrm{P}\right] \mathrm{ATP}$ to histone. The standard reaction mixture contained $20 \mathrm{~m} M$ Tris- $\mathrm{HCl}$ (pH 7.5), $5 \mathrm{~m} M$ magnesium acetate, $45 \mu M \mathrm{CaCl}_{2}, 200 \mu \mathrm{g}$ histone III-S/ml, $250 \mu M\left[\gamma_{-}{ }^{32} \mathrm{P}\right] \mathrm{ATP}, 160 \mu \mathrm{g}$ phosphatidylserine $/ \mathrm{ml}, 1.6 \mu \mathrm{g}$ diolein $/ \mathrm{ml}$, and the enzyme solution to be assayed in a final volume of $250 \mu \mathrm{l}$. Phosphatidylserine and diolein were dried from chloroform and sonicated in $20 \mathrm{~m} M$ Tris- $\mathrm{HCl}(\mathrm{pH} 7.5)$. The reactions were performed in plastic tubes and were initiated by the addition of 30 and $50 \mu \mathrm{l}$ of the cytosol and membrane fractions, respectively. After 5 min at $30^{\circ} \mathrm{C}$, the assay was terminated by the addition of 3 $\mathrm{ml}$ of $25 \%$ trichloroacetic acid (TCA) and filtered over a Millipore filter $(0.45 \mu \mathrm{m})$. The tubes were washed three times with $25 \%$ TCA and the contents added to the filter; two further TCA washes of the filter followed. PKC activity was computed according to the following equation:

$$
\text { PKC activity }=A-(B-C)
$$

where $A=$ the amount of ${ }^{32} \mathrm{P}$ incorporation into histone in the presence of tissue extract, $\mathrm{Ca}^{2+}$, phosphatidylserine, and diolein; $B=$ the amount of ${ }^{32} \mathrm{P}$ incorporation into histone in the presence of $\mathrm{Ca}^{2+}$ and tissue extract; and $C=$ the amount of ${ }^{32} \mathbf{P}$ incorporation into histone in the presence of $20 \mathrm{mM}$ EGTA and tissue extract (no $\mathrm{Ca}^{2+}$, phosphatidylserine, or diolein).

Background activity was determined in samples in which tissue, phosphatidylserine, diolein, and $\mathrm{Ca}^{2+}$ were omitted and an additional $20 \mathrm{mM}$ EGTA added.

\section{Data analysis}

Results are expressed as mean \pm SEM values. Student's $t$ tests (paired or unpaired) were used to determine statistical significance. Proteins were measured according to the method of Geiger and Bessman (1972), except for the PKC assay, where interference from assay reagents necessitated the use of Bio-Rad Protein Assay. Apparent $K_{\mathrm{i}}$ values for radioligand binding studies were calculated from the Cheng and Prusoff equation (1973). Competition curves were analyzed by the LIGAND program (Munson and Rodbard, 1980). Saturation isotherms were analyzed according to the Scatchard transformation (1949).

\section{RESULTS}

\section{Characterization of muscarinic acetylcholine receptors on SH-SY5Y cells}

Because some uncertainty exists regarding the pharmacological identity of the muscarinic receptors present on SH-SY5Y cells (Adem et al., 1987; Serra et al., 1988; Lambert et al., 1989), our initial studies were directed toward a pharmacological and biochemical characterization of the receptor subtype expressed in the cell line used during the course of the present study. When $\left[{ }^{3} \mathrm{H}\right] \mathrm{NMS}$ and $\left[{ }^{3} \mathrm{H}\right]$ scopolamine were utilized to characterize muscarinic receptors, both ligands labeled receptors on intact, confluent SH-SYSY cells $(\sim 12$ days in culture) in a specific and saturable manner yielding $B_{\max }$ values of $352 \pm 38$ and $397 \pm 2 \mathrm{fmol} /$ mg of protein $(\mathrm{n}=3)$, respectively (Fig. 1); the average $K_{\mathrm{D}}$ values were $0.82 \pm 0.23$ and $0.95 \pm 0.20 \mathrm{n} M$, respectively. The $\mathrm{M}_{1}$-selective antagonist pirenzepine was able to compete for all sites labeled by $\left[{ }^{3} \mathrm{H}\right] \mathrm{NMS}$ (Fig. 2). The $K_{\mathrm{i}}$ value obtained for pirenzepine displacement was $700 \pm 100 \mathrm{nM}(\mathrm{n}=3)$, indicating the presence of a class of muscarinic receptors with low affinity for the antagonist, in agreement with the results of Lambert et al. (1989). Although the Hill coefficients $(0.89 \pm 0.03$; Fig. 2) were significantly less than $1.0(p<0.05)$, the data could only be successfully fit by LIGAND according to a one-site model. However, a small number of high-affinity pirenzepine binding sites has been detected in two previous reports using this clone (Adem et al., 1987; Serra et al., 1988).

SH-SY5Y cells are a subclone of the parent SK-NSH neural cell line (Biedler et al., 1978), which has been found to exhibit an $\mathrm{M}_{3}$ muscarinic subtype that couples to PPI turnover (Fisher and Heacock, 1988). To investigate whether SH-SY5Y neuroblastoma cells express the same muscarinic receptor subtype as the parent cell line, intact SH-SY5Y cells were labeled with 


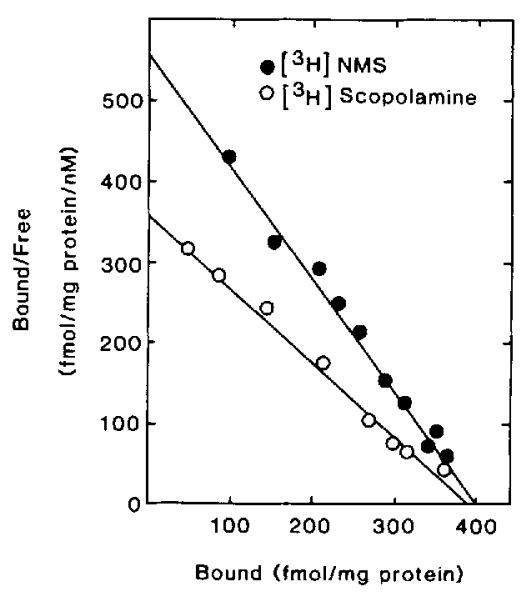

FIG. 1. Scatchard analysis of the binding of $\left[{ }^{3} H\right] N M S$ and $\left[{ }^{3} \mathrm{H}\right]$ scopolamine to muscarinic receptors on intact $\mathrm{SH}-\mathrm{SY} 5 \mathrm{Y}$ cells. SH-SY5Y cells $(\sim 400 \mu \mathrm{g}$ of protein) were incubated with either 0.2-5.0 $\mathrm{nM}\left[{ }^{3} \mathrm{H}\right] \mathrm{NMS}$ or 0.15-10.0 $\mathrm{nM}\left[{ }^{3} \mathrm{H}\right]$ scopolamine for 120 $\min$ at $37^{\circ} \mathrm{C}$. Nonspecific binding was assessed in the presence of $50 \mu M$ atropine. Results shown are representative of three independent experiments.

$\left[{ }^{3} \mathrm{H}\right] \mathrm{PBCM}$ and the labeled peptides analyzed by sodium dodecyl sulfate-urea gel electrophoresis. A major labeled species of $M_{r} 98,000$ was detected, as previously observed for the parent SK-N-SH cell line (Fig. 3; Fisher and Heacock, 1988). Taken together, these findings suggest that the SH-SY5Y cell line used in the present study contains a high density of high molecular weight muscarinic receptors of the $\mathrm{M}_{3}$ (pirenzepine low-affinity) subtype, and are in agreement with the pharmacological data recently presented by Lambert et al. (1989) for the same cell line. Furthermore, both the biochemical and pharmacological properties of the muscarinic receptors present on SH-SY5Y neuroblastoma cells appear to be very similar to those observed

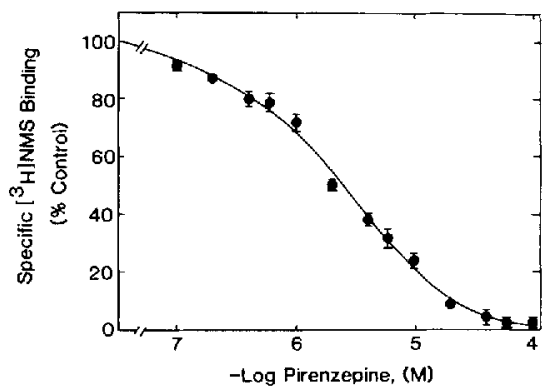

FIG. 2. Competition for specific $\left[{ }^{3} \mathrm{H}\right] \mathrm{NMS}$ binding sites by pirenzepine in SH-SY5Y cells. Intact cells were incubated for 120 min at $37^{\circ} \mathrm{C}$ with $5 n M\left[{ }^{3} \mathrm{H}\right] \mathrm{NMS}$ in the presence of increasing concentrations of pirenzepine. The specific $\left[{ }^{3} \mathrm{H}\right] \mathrm{NMS}$ binding in the absence of displacer was $219 \mathrm{fmol} / \mathrm{mg}$ of protein. Data shown are from three independent experiments with an average Hill coefficient value of $0.89 \pm 0.03$ (significantly different from 1.0; $p<0.05$ ). However, in each experiment, the displacement data (up to 21 points) were only successfully fit by LIGAND to a one-site model.

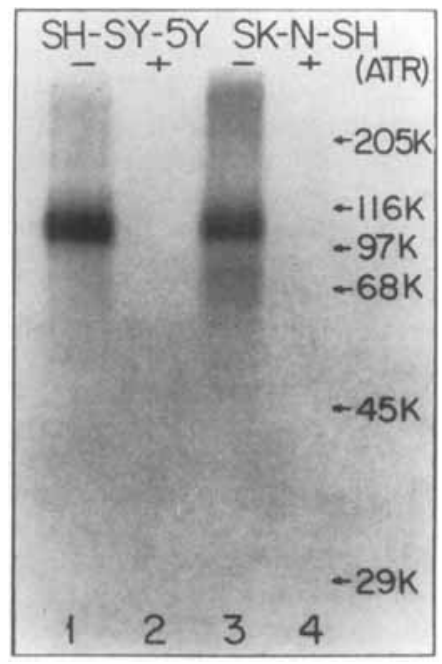

FIG. 3. A high $M_{r}$ muscarinic receptor is present in both $\mathrm{SH}-\mathrm{SY} 5 \mathrm{Y}$ and SK-N-SH neuroblastoma cells. Intact SH-SY5Y cells (lanes 1 and 2) or SK-N-SH cells (lanes 3 and 4) were labeled with $\left[{ }^{3} \mathrm{H}\right] \mathrm{PBCM}$, and labeled peptides were then analyzed by sodium dodecyl sulfateurea gel electrophoresis. Samples in lanes 2 and 4 were incubated with $10 \mu M$ atropine prior to labeling with $\left[{ }^{3} \mathrm{H}\right] \mathrm{PBCM}$. The molecular weight markers, in order of decreasing $M_{r}$, were myosin, $\beta$-galactosidase, phosphorylase $b$, bovine serum albumin, ovalbumin, and carbonic anhydrase.

for the parent SK-N-SH cell line (Fisher and Heacock, 1988).

Changes in cell morphology of SH-SY5Y cells treated with either TPA or mezerein or cultured in the absence of fetal calf serum

SH-SY 5 Y cells, cultured for up to 5 days in the presence of $50 \mathrm{n} M$ TPA, expressed long, neuritic processes indicative of neuronal differentiation, as previously described (Pahlman et al., 1981, 1984; Adem et al., 1987; Heikkila et al., 1987). Identical morphological changes were induced by treatment with $100 \mathrm{nM}$ mezerein. When SH-SY5Y cells were cultured for up to 7 days in media devoid of fetal calf serum, morphologically differentiated cells also resulted. Although these cells had long, straight processes, the appearance of many cell clusters and greater distances between cells made them morphologically distinct from cells treated with TPA or mezerein.

\section{Changes in muscarinic receptor density and ${ }^{3} \mathrm{H}$-inositol phosphate generation following long-term TPA treatment}

Addition of $50 \mathrm{n} M$ TPA to newly passaged cells for various times resulted in a gradual, time-dependent loss of both $\left[{ }^{3} \mathrm{H}\right] N M S$ and $\left[{ }^{3} \mathrm{H}\right]$ scopolamine binding sites to $\sim 70 \%$ of control values at 5 days (Fig. 4). Under similar conditions, there was also a time-dependent, albeit larger, inhibition of muscarinic receptor-stimulated accumulation of ${ }^{3} \mathrm{H}$-inositol phosphates (Fig. 4). Acute exposure of SH-SY5Y cells to $50 \mathrm{n} M$ TPA for either $15 \mathrm{~min}$ or $18 \mathrm{~h}$ had little or no effect on specific 


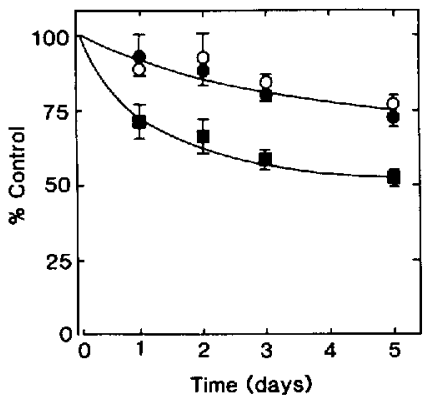

FIG. 4. Time course of TPA-induced decrease in muscarinic receptor density and of carbamylcholine-stimulated ${ }^{3} \mathrm{H}$-inositol phosphate generation. SH-SY5Y cells were pretreated with $50 \mathrm{nM}$ TPA for the designated times and harvested for assay as described in Materials and Methods. Binding to muscarinic receptors was determined by incubating intact cells with $5 \mathrm{nM}\left[{ }^{3} \mathrm{H}\right] \mathrm{NMS}(\bullet)$ or $8 \mathrm{nM}$ $\left[{ }^{3} \mathrm{H}\right]$ scopolamine $(\mathrm{O})$ in the presence or absence of $50 \mu \mathrm{M}$ atropine for $120 \mathrm{~min}$ at $37^{\circ} \mathrm{C}$. For the sake of clarity, one line has been drawn to designate the binding of both ligands to muscarinic receptors. Total ${ }^{3} \mathrm{H}$-inositol phosphate release (D) was measured as described in Materials and Methods using $10 \mathrm{mM}$ carbamylcholine. Data are expressed relative to control cells, which were not pretreated with TPA, and are presented as the mean of three to four independent experiments.

$\left[{ }^{3} \mathrm{H}\right]$ NMS binding ( $>94 \%$ of control) or agonist-stimulated PPI hydrolysis ( $>95 \%$ of control). To further characterize the TPA-induced diminution of muscarinic receptor density and of ${ }^{3} \mathrm{H}$-inositol phosphate generation, all subsequent experiments were performed with a standard 5-day, 50-n $M$ TPA pretreatment period.

Scatchard analysis of $\left[{ }^{3} \mathrm{H}\right] \mathrm{NMS}$ binding in untreated cells revealed a $B_{\max }$ of $345 \pm 29 \mathrm{fmol} / \mathrm{mg}$ of protein $(\mathrm{n}=4)$, with a corresponding $K_{\mathrm{D}}$ value of $0.82 \pm 0.09$ $\mathrm{n} M$ (Fig. 5). However, cells treated for 5 days with 50 $\mathrm{n} M$ TPA exhibited a significant $27 \%$ decline in the $B_{\max }$ of $\left[{ }^{3} \mathrm{H}\right] \mathrm{NMS}$ binding $(p<0.05)$ without a significant change in the $K_{\mathrm{D}}$ for the ligand. Saturation isotherms for the TPA-treated group revealed average $B_{\max }$ and

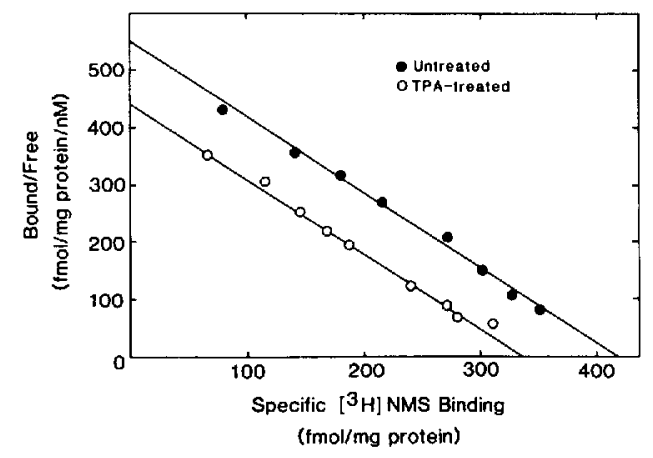

FIG. 5. The effect of long-term TPA treatment on the binding properties of $\left[{ }^{3} \mathrm{H}\right] \mathrm{NMS}$. Intact $\mathrm{SH}-\mathrm{SY} 5 \mathrm{Y}$ cells were incubated with increasing concentrations of $\left[{ }^{3} \mathrm{H}\right] \mathrm{NMS}$ for $120 \mathrm{~min}$ at $37^{\circ} \mathrm{C}$. Nonspecific binding was obtained in the presence of $50 \mu M$ atropine. All data points were determined in duplicate, and results from one of four similar experiments are shown.
$K_{\mathrm{D}}$ values of $252 \pm 36 \mathrm{fmol} / \mathrm{mg}$ of protein and 0.83 $\pm 0.09 \mathrm{n} M$, respectively (Fig. 5). Similarly, when $\left[{ }^{3} \mathrm{H}\right]$ scopolamine was utilized as the radioligand, a $27 \%$ reduction in $B_{\max }$, with no change in $K_{\mathrm{D}}$, was observed following TPA treatment (data not shown).

To determine whether the inhibition of muscarinic receptor-mediated hydrolysis of inositol lipids was a result of a decrement in the maximal response and/or a change in agonist potency, we examined the ability of increasing concentrations of carbamylcholine to generate ${ }^{3} \mathrm{H}$-inositol phosphates in untreated and TPAtreated cells. The results demonstrate that TPA pretreatment reduces the extent of agonist-stimulated inositol phosphate release by decreasing the maximal response without changing the $\mathrm{EC}_{50}$ value (Fig. 6). Basal ${ }^{3} \mathrm{H}$-inositol phosphate release was unaffected by prior treatment of SH-SY5Y cells with TPA.

\section{Muscarinic receptor density and stimulated PPI hydrolysis in SH-SY5Y cells grown in serum-free media}

To determine whether differentiation of SH-SY5Y cells invariably leads to alterations in muscarinic receptor signal transduction events, differentiation also was induced by removal of fetal calf serum from the medium. A small, although not significant $(p>0.05)$, increase in specific $\left[{ }^{3} \mathrm{H}\right] \mathrm{NMS}$ binding $(130 \pm 20 \%$ of control, $n=3$ ) was observed in SH-SY $5 Y$ cells grown for 6-7 days in serum-free media. Similarly, carbamylcholine-stimulated ${ }^{3} \mathrm{H}$-inositol phosphate production increased to $136 \pm 16 \%$ of control $(n=3)$. However, a greater incorporation of $m y o-\left[{ }^{3} \mathrm{H}\right]$ inositol into the inositol lipid pool in cells grown without serum (156 $\pm 4 \%$ of control) may account for much of this increase in inositol phosphate release. These results suggest that the differentiation of SH-SY5Y cells is not

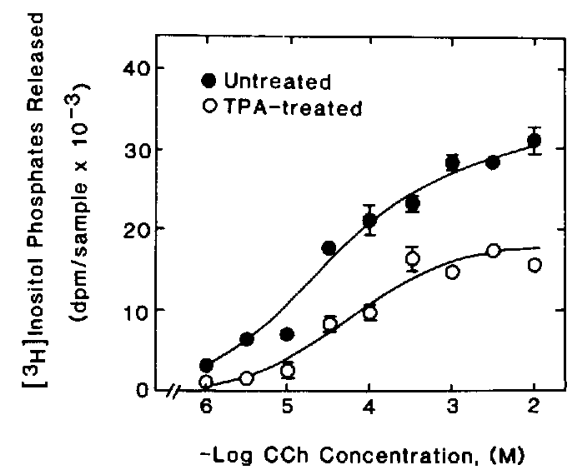

FIG. 6. Dose-response curves of carbamylcholine (CCh)-stimulated accumulation of ${ }^{3} \mathrm{H}$-inositol phosphates in untreated and TPAtreated SH-SY5Y cells. Intact human neuroblastoma cells were treated with or without $50 \mathrm{nM}$ TPA for 5 days and incubated with $\mathrm{CCh}$ at the indicated concentrations. TPA treatment did not alter basal ${ }^{3} \mathrm{H}$-inositol phosphate release. Values shown are means for triplicate samples obtained from a single experiment. $E_{50}$ values for CCh (calculated by log-probit analysis) were 60 and $62 \mu M$ for untreated and TPA-treated cells, respectively. 
necessarily accompanied by changes in muscarinic receptor-effector coupling.

Comparison of the effects of phorbol esters and mezerein on muscarinic receptor number and stimulated PPI hydrolysis

It was consistently noted that TPA produced a greater reduction in carbamylcholine-stimulated ${ }^{3} \mathrm{H}$ inositol phosphate generation than in muscarinic receptor density, whereas the biologically inactive $4 \alpha-$ PDD was without effect on both of these parameters (Table 1). On the other hand, mezerein was able to mimic the effects produced by TPA and elicited a 26 and $53 \%$ inhibition of specific $\left[{ }^{3} \mathbf{H}\right]$ NMS binding and ${ }^{3} \mathrm{H}$-inositol phosphate generation, respectively (Table 1). Neither TPA nor mezerein pretreatment influenced the incorporation of $m y o-\left[{ }^{3} \mathrm{H}\right]$ inositol into the inositol lipid pool under basal (no agonist) conditions [ $98 \pm 6 \%$ $(n=6)$ and $104 \pm 8 \%(n=4)$ of control for TPA and mezerein, respectively]. When SH-SY5Y cells were cultured in the presence of both TPA and mezerein, less than additive effects resulted (data not shown). Thus, these agents appear to mediate their effects through a similar pathway or mechanism.

\section{Changes in $\left[\mathrm{Ca}^{2+}\right]_{i}$ in SH-SY5Y cells following treatment with TPA or mezerein}

The fluorescent indicator, fura-2, was utilized to monitor both basal and agonist-stimulated $\left[\mathrm{Ca}^{2+}\right]_{\mathrm{i}}$ values in human neuroblastoma cells. Under resting conditions, a basal $\left[\mathrm{Ca}^{2+}\right]_{\mathrm{i}}$ value of $39 \pm 4 \mathrm{n} M(\mathrm{n}=13)$ was obtained in untreated SH-SY5Y cells. Upon agonist addition, a rapid rise of $\left[\mathrm{Ca}^{2+}\right]_{\mathrm{i}}$ to a value of 350 $\pm 24 \mathrm{n} M(\mathrm{n}=13)$ was observed (Fig. 7A). This increase was transient and was followed by a decline to a plateau phase of the $\left[\mathrm{Ca}^{2+}\right]_{\mathrm{i}}$ signal (Fig. 7A; see Fisher et al., 1989). Subsequent addition of atropine reduced the plateau $\mathrm{Ca}^{2+}$ value to that of basal $\left[\mathrm{Ca}^{2+}\right]_{\mathrm{i}}$ (Fig. 7A).

TABLE 1. Effect of phorbol esters and mezerein on muscarinic receptor number and on muscarinic receptor-mediated generation of inositol phosphates

\begin{tabular}{|c|c|c|}
\hline \multirow[b]{2}{*}{ Treatment } & \multicolumn{2}{|c|}{$\%$ control } \\
\hline & $\begin{array}{c}\text { Specific } \\
{\left[{ }^{3} \mathrm{H}\right] \mathrm{NMS}} \\
\text { binding }(\mathrm{n})\end{array}$ & $\begin{array}{l}\text { Agonist-stimulated } \\
{ }^{3} \mathrm{H}-\mathrm{IP} \text { generation } \\
\text { (n) }\end{array}$ \\
\hline TPA, $50 \mathrm{n} M$ & $72 \pm 3^{a}(7)$ & $52 \pm 4^{a}(6)$ \\
\hline $4 \alpha-\mathrm{PDD}, 1,000 \mathrm{n} M$ & $99 \pm 8(3)$ & $103 \pm 4(4)$ \\
\hline Mezerein, $100 \mathrm{n} M$ & $74 \pm 6^{a}(4)$ & $47 \pm 8^{a}(4)$ \\
\hline
\end{tabular}

SH-SY $5 Y$ cells were treated for 5 days and values for $\left[{ }^{3} \mathrm{H}\right] \mathrm{NMS}$ binding and ${ }^{3} \mathrm{H}$-inositol phosphate $\left({ }^{3} \mathrm{H}\right.$-IP) generation are expressed relative to control cells, which were treated identically except for absence of drug treatment. Cells were incubated with $5 \mathrm{n} M\left[{ }^{3} \mathrm{H}\right] N M S$ with or without $50 \mu \mathrm{M}$ atropine for $120 \mathrm{~min}$ at $37^{\circ} \mathrm{C}$. Generation of total ${ }^{3} \mathrm{H}$-IP was determined in the presence of $10 \mathrm{~m} M$ carbamylcholine. Values represent the means \pm SEM for the number $(n)$ of separate experiments indicated.

${ }^{u}$ Significantly different from control, $p<0.05$.

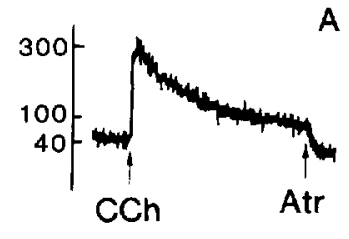

A
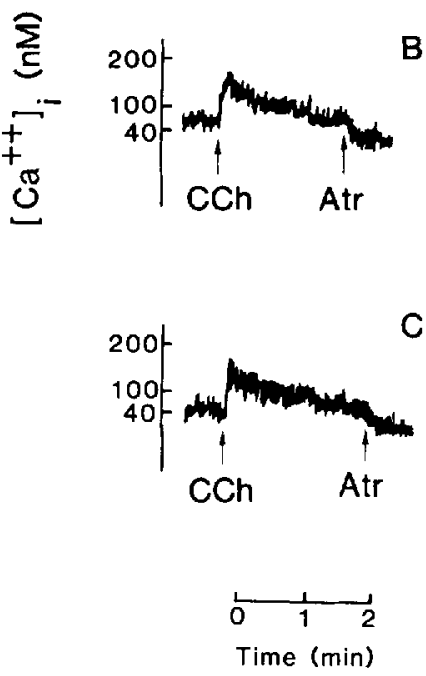

FIG. 7. Effect of TPA and mezerein on the agonist-induced rise in $\left[\mathrm{Ca}^{2+}\right]_{i}$ in SH-SY5Y cells. Intact cells were loaded with $2 \mu \mathrm{M}$ fura-2/AM for $15 \mathrm{~min}$ at $37^{\circ} \mathrm{C}$. Cells were exposed to $10 \mathrm{mM}$ carbamylcholine (CCh) and $10 \mu \mathrm{M}$ atropine (Atr) at the times indicated. Representative traces are shown for untreated cells (A) and cells treated for 5 days with $50 \mathrm{nM}$ TPA (B) or $100 \mathrm{nM}$ mezerein (C).

TPA and mezerein pretreatment had no effect on resting $\left[\mathrm{Ca}^{2+}\right]_{\mathrm{i}}$. Thus, basal $\left[\mathrm{Ca}^{2+}\right]_{\mathrm{i}}$ values of $40 \pm 4 \mathrm{nM}$ $(\mathrm{n}=9)$ and $44 \pm 3 \mathrm{n} M(\mathrm{n}=10)$ were obtained for TPA- and mezerein-treated SH-SY5Y cells, respectively. However, a significant reduction $(51-53 \%)$ in the magnitude of the initial rise in $\left[\mathrm{Ca}^{2+}\right]_{\mathrm{i}}$ was noted following chronic exposure of cells to these agents (Fig. $7 \mathrm{~B}$ and $\mathrm{C}$ ). The peak $\left[\mathrm{Ca}^{2+}\right]_{\mathrm{i}}$ achieved following addition of carbamylcholine to TPA-treated cells was 193 $\pm 9 \mathrm{n} M(\mathrm{n}=9)$, whereas that for cells treated with mezerein was $191 \pm 16 \mathrm{n} M(\mathrm{n}=10)$. A similar decline in agonist-stimulated $\left[\mathrm{Ca}^{2+}\right]_{i}$ values was obtained in TPA- and mezerein-treated cells when muscarine was utilized as the agonist (data not shown).

\section{Pretreatment of SH-SY5Y cells with TPA or mezerein depletes total PKC activity}

Chronic exposure of cells to phorbol esters has been reported to induce the down-regulation of PKC activity. To determine the effects of long-term treatment with TPA and mezerein on levels of PKC, the activity of this enzyme was measured in both cytosol and membrane fractions obtained from SH-SY5Y cells treated for 5 days with these agents. In untreated cells, $70 \%$ of total PKC activity was associated with the cytosolic fraction, with the remainder localized to the 
membrane (Table 2). A decrease in the amount of total PKC activity was apparent after treatment with $50 \mathrm{n} M$ TPA for 5 days, with levels of the enzyme reaching only $16 \%$ of control (Table 2). Pretreatment with 100 $\mathrm{n} M$ mezerein also led to a similar depletion of PKC activity (Table 2).

TPA and mezerein treatments inhibit NaF- and GTP $\gamma$ S-stimulated inositol phosphate production

Because the loss of muscarinic receptors could not fully account for the decrement observed in stimulated PPI hydrolysis, we investigated the possibility that TPA and mezerein were inhibiting inositol phosphate generation at an additional site distal to the receptor. Intact SH-SY $5 Y$ cells were prelabeled for $24 \mathrm{~h}$ and then challenged with $\mathrm{NaF}$, a compound capable of stimulating the accumulation of inositol phosphates via direct interaction with $G_{p}$. Table 3 shows that prior treatment of human neuroblastoma cells with TPA or mezerein significantly impaired the ability of $\mathrm{NaF}$ to induce ${ }^{3} \mathrm{H}$ inositol phosphate generation when compared with untreated cells. Under these conditions, carbamylcholine-stimulated ${ }^{3} \mathrm{H}$-inositol phosphate formation was reduced to the same extent as that reported using the acute labeling paradigm (Tables 1 and 3 ).

The site of TPA- and mezerein-induced inhibition of PPI hydrolysis was investigated further utilizing digitonin-permeabilized cells stimulated with GTP $\gamma \mathrm{S}$, a nonhydrolyzable analog of GTP. Addition of either GTP $\gamma \mathrm{S}$ or carbamylcholine led to an increase in ${ }^{3} \mathrm{H}$ inositol phosphate generation in untreated cells, whereas a combination of both agents resulted in a synergistic accumulation (Fig. 8). Inclusion of $3 \mathrm{mM}$ guanosine $5^{\prime}-O$-(2-thiodiphosphate) (GDP $\beta S$ ) substantially $(40-70 \%)$ reduced carbamylcholine-stimulated and carbamylcholine plus GTP $\gamma$ S-stimulated ${ }^{3} \mathrm{H}$-inositol phosphate release from permeabilized cells. Furthermore, inclusion of $20 \mu M$ atropine attenuated stimulated PPI turnover observed in the presence of

TABLE 2. PKC activity in cytosol and membrane fractions of untreated, TPA-treated, and mezerein-treated SH-SY5Y cells

\begin{tabular}{lccccc}
\hline & \multicolumn{4}{c}{ PKC activity } \\
\cline { 2 - 3 } & \multicolumn{2}{c}{ Cytosol } & & \multicolumn{2}{c}{ Membrane } \\
\cline { 2 - 3 } \cline { 5 - 6 } & $\begin{array}{c}\text { pmol/min/mg } \\
\text { of protein }\end{array}$ & $\begin{array}{c}\% \\
\text { control }\end{array}$ & $\begin{array}{c}\text { pmol/min/mg } \\
\text { of protein }\end{array}$ & $\begin{array}{c}\% \\
\text { control }\end{array}$ \\
\hline Untreated & 54.3 & & 27.4 & \\
TPA & 8.5 & 15.7 & & 4.5 & 16.4 \\
Mezerein & 9.8 & 18.2 & & 3.1 & 11.3 \\
\hline
\end{tabular}

Intact SH-SY5Y cells were pretreated with the designated agents for 5 days. Homogenates were prepared and PKC activity (phosphatidylserine + diolein-induced ${ }^{32} \mathrm{P}$ phosphorylation of histone III-S) was determined in cytosolic and membrane fractions as described in Materials and Methods. Data are the average from two independent experiments, which differed by $<10 \%$.
TABLE 3. Pretreatment with TPA and mezerein reduces the ability of fluoride to stimulate ${ }^{3} \mathrm{H}$-inositol phosphate production in human SH-SY5Y neuroblastoma cells

\begin{tabular}{lcc}
\hline & \multicolumn{2}{c}{$\begin{array}{c}{ }^{3} \mathrm{H} \text {-Inositol phosphates produced } \\
(\% \text { control) }\end{array}$} \\
\cline { 2 - 3 } & Fluoride & Carbamylcholine \\
\hline TPA & $60.3 \pm 7.7$ & $51.7 \pm 3.3$ \\
Mezerein & $55.8 \pm 2.8$ & $42.9 \pm 2.7$ \\
\hline
\end{tabular}

Intact SH-SY $5 Y$ cells were treated with or without $50 \mathrm{nM}$ TPA or $100 \mathrm{n} M$ mezerein for 5 days and prelabeled with $m y o-\left[{ }^{3} \mathrm{H}\right]$ inositol $(5 \mu \mathrm{Ci} / \mathrm{ml})$ for the last day of this treatment. Intact, prelabeled cells $(\sim 500 \mu \mathrm{g}$ of protein) were incubated with $30 \mathrm{mM} \mathrm{NaF}$ or $10 \mathrm{mM}$ carbamylcholine for $20 \mathrm{~min}$ at $37^{\circ} \mathrm{C}$. Results represent the means from four independent experiments. In pretreated cells, ${ }^{3} \mathrm{H}$-inositol phosphate release in basal and in fluoride- and carbamylcholinestimulated incubations were $1,277 \pm 334,3,790 \pm 610$, and 22,962 $\pm 4,033 \mathrm{dpm} / \mathrm{mg}$ of protein, respectively. In untreated cells, a combination of fluoride and carbamylcholine resulted in accumulation of ${ }^{3} \mathrm{H}$-inositol phosphate generation greater than that observed with fluoride alone, but less than the maximal stimulation noted in the presence of agonist alone.

carbamylcholine plus GTP $\gamma \mathrm{S}$ to the level obtained for GTP $\gamma \mathrm{S}$ alone, as previously observed for the SK-NSH cell line (Fisher et al., 1989). The ability of carbamylcholine to increase ${ }^{3} \mathrm{H}$-inositol phosphate release was reduced in TPA- and mezerein-treated SH-SY5Y cells to about $30 \%$ of control values (Fig. 8). GTP $\gamma$ Sstimulated ${ }^{3} \mathrm{H}$-inositol phosphate release was decreased to 71 and $66 \%$ of control in cells treated with TPA and mezerein, respectively. Although a combination of

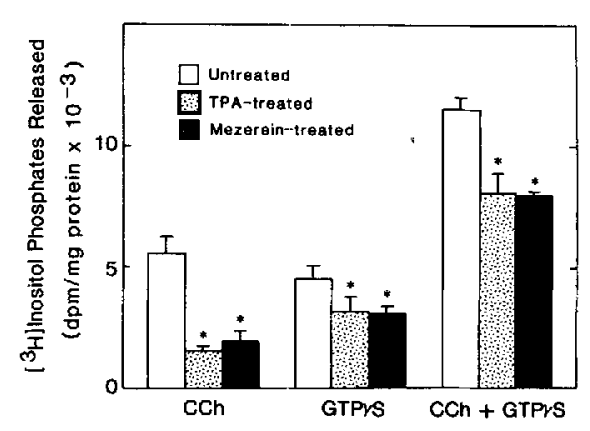

FIG. 8. Effect of TPA and mezerein pretreatment on carbamylcholine (CCh)- and GTP $\gamma$ S-induced inositol phosphate release in permeabilized SH-SY5Y cells. Human neuroblastoma cells were treated with or without $50 \mathrm{nM}$ TPA or $100 \mathrm{~g} M$ mezerein for 5 days. $\left[{ }^{3} \mathrm{H}\right]$ Inositol-prelabeled cells were permeabilized with digitonin at a protein concentration of $\sim 4 \mathrm{mg} / \mathrm{ml}$. Cells were then incubated with either $50 \mu \mathrm{M}$ GTP $\gamma \mathrm{S}, 10 \mathrm{mM} \mathrm{CCh}$, or both for $15 \mathrm{~min}$ at $37^{\circ} \mathrm{C}$. A combination of $\mathrm{CCh}$ and $\mathrm{GTP} \gamma \mathrm{S}$ elicited a significant synergistic effect $(\rho<0.05)$ in three of four experiments performed in untreated permeabilized cells and in all experiments in permeabilized cells from both TPA- and mezerein-treated groups. The $\mathrm{Ca}^{2+}$ concentration was maintained at $60 \mathrm{nM}$ (Fisher et al., 1989). Inositol lipid labeling and basal ${ }^{3} \mathrm{H}$-inositol phosphate release remained unaffected by pretreatment with TPA or mezerein. Results shown are the means from three to four separate experiments. "Significantly different from untreated cells $(p<0.05)$. 
carbamylcholine and GTP $\gamma \mathrm{S}$ still elicited a synergistic effect in permeabilized cells obtained from both treated groups, the maximal stimulation was reduced to $70 \%$ when compared with untreated cells. Basal release of ${ }^{3} \mathrm{H}$-inositol phosphates was not appreciably altered in treated cells. Direct activation of phospholipase $\mathrm{C}$ activity by the addition of $2 \mathrm{mM} \mathrm{CaCl} 2$ to digitonin-permeabilized cells resulted in a five- to sevenfold increase in ${ }^{3} \mathrm{H}$-inositol phosphate release over basal levels. This ability of $\mathrm{Ca}^{2+}$ to activate the enzyme directly was not impaired in cells pretreated with either TPA or mezerein for 5 days (88-102\% of control, $\mathbf{n}=2$ ). Taken together, the results suggest that treatments with TPA and mezerein inhibit not only muscarinic agonist-induced ${ }^{3} \mathrm{H}$-inositol phosphate formation but also that resulting from direct activation of $G_{p}$.

\section{DISCUSSION}

The principal conclusion to emerge from the present study is that although long-term treatment of human neuroblastoma SH-SY5Y cells with TPA or mezerein results in a loss of muscarinic receptor number, a more pronounced reduction is observed for two biochemical consequences of receptor activation, namely agoniststimulated PPI hydrolysis and $\mathrm{Ca}^{2+}$ signaling. Evidence obtained from both intact and permeabilized cells indicates that an additional site of action of these tumor promoters, at the level of $\mathrm{G}_{\mathrm{p}}$-stimulated PPI hydrolysis, may account for their marked inhibitory effects on inositol lipid signaling events.

In agreement with previous reports (Adem et al., 1987; Heikkila et al., 1987), chronic treatment of SHSY5Y cells with TPA resulted in a loss of muscarinic receptor binding sites, reaching a maximal steady state after 5 days of treatment (Fig. 4 and Table 1). Comparable losses of both $\left[{ }^{3} \mathrm{H}\right]$ scopolamine and $\left[{ }^{3} \mathrm{H}\right] \mathrm{NMS}$ binding indicate that both cell surface and sequestered muscarinic receptors are equally down-regulated following chronic TPA treatment (Fig. 4). Acute exposure of intact, confluent SH-SY5Y cells with $50 \mathrm{nM}$ TPA did not alter muscarinic receptor density. In contrast, a loss of muscarinic receptors has been reported for other cell lines following acute exposure to a similar concentration of TPA (Liles et al., 1986; Pearce et al., 1988).

Although muscarinic receptor density was reduced following chronic TPA and mezerein treatment, a consistently larger attenuation of agonist-induced PPI hydrolysis was observed (Table 1). This effect is due to a decreased maximal response without a change in the potency of the agonist for the receptor (Fig. 6). Utilizing intact and digitonin-permeabilized SH-SY 5 Y cells, we obtained evidence that TPA and mezerein induce additional inhibitory effects on PPI hydrolysis at a site distal to the receptor. Pretreatment of cells with TPA or mezerein significantly reduced the ability of fluoride, an agent that causes activation of $G_{p}$ through its dissociation, to stimulate PPI hydrolysis (Table 3). Sim- ilarly, the ability of GTP $\gamma$ S to enhance inositol phosphate release from digitonin-permeabilized cells also was diminished following pretreatment with these agents (Fig. 8). TPA and mezerein did not affect the basal incorporation of myo- $\left[{ }^{3} \mathrm{H}\right]$ inositol into the inositol lipid pool, suggesting that substrate depletion probably does not account for the TPA- and mezereininduced reduction in PPI hydrolysis. Thus, the present results are consistent with the possibility that in SHSY5Y cells, treatment with either tumor promoter results in inhibition of stimulated PPI hydrolysis at a site either at or distal to $G_{p}$. Although inhibition of receptor-stimulated PPI hydrolysis following acute exposure of tissues to relatively high concentrations of phorbol esters is well documented (see Snider et al., 1987 and references therein), the underlying mechanism remains uncertain. In this context, inhibition of the $G$ protein interaction with phospholipase $\mathrm{C}$ following acute TPA treatment has been demonstrated previously for $1321 \mathrm{~N} 1$ human astrocytoma cells (Orellana et al., 1987) and HL60 cells (Cockcroft and Stutchfield, 1988; Geny et al., 1989), but not for primary astrocyte cultures (Pearce et al., 1988). Thus, the mechanism of TPA-induced inhibition of stimulated PPI hydrolysis may be tissue-specific.

Pretreatment of SH-SY5Y cells with TPA or mezerein also resulted in a reduction in the carbamylcholinestimulated rise in $\left[\mathrm{Ca}^{2+}\right]_{\mathrm{i}}$ to an extent similar to that observed for stimulated PPI hydrolysis $(\sim 50 \%)$. In contrast, no effect of the tumor promoters on basal $\left[\mathrm{Ca}^{2+}\right]_{\mathrm{i}}$ was observed. These results indicate that the magnitude of the rise in $\left[\mathrm{Ca}^{2+}\right]_{\mathrm{i}}$ is proportional to the extent of PPI hydrolysis and suggest that these two events are closely coupled in SH-SY5Y cells, as previously noted for SK-N-SH neuroblastoma cells (Fisher et al., 1989).

In the SH-SY5Y neuronal cell line, mezerein elicited morphological and biochemical changes similar to those induced by TPA (Table 1), suggesting that these two agents function through a similar pathway or mechanism. Despite the fact that mezerein does not contain a diacylglycerol-like molecule in its structure, the compound is capable of activating PKC both in vitro and in vivo in a manner analogous to TPA (Miyake et al., 1984). In our study, long-term exposure to TPA or mezerein led to a marked depletion of total PKC activity in SH-SY5Y cells (Table 2). These results are consistent with the occurrence of down-regulation of PKC activity upon chronic exposure to phorbol esters, as observed for other cultured cell lines (Ballester and Rosen, 1985; Blackshear et al., 1985; Hepler et al., 1988). Conversely, $4 \alpha-\mathrm{PDD}$, which does not activate PKC, did not reduce either specific $\left[{ }^{3} \mathrm{H}\right] \mathrm{NMS}$ binding or stimulated PPI hydrolysis (Table 1), providing further evidence that activation of PKC is involved, at least in part, in the long-term effects of biologically active tumor promoters. Inhibition of guanine nucleotide-stimulated PPI hydrolysis in SH-SY5Y cells following TPA or mezerein treatment may reflect PKC- 
mediated phosphorylation of $G_{p}$, as previously proposed to occur in $1321 \mathrm{Nl}$ astrocytoma cells (Orellana et al., 1987). TPA treatment of platelets results in the PKC-induced phosphorylation of the inhibitory guanine nucleotide regulatory protein $\mathrm{G}_{\mathbf{i}}$ (Katada et al., 1985). Alternatively, PKC may directly phosphorylate phospholipase C itself (Rhee et al., 1989). However, this possibility appears less likely in SH-SY5Y cells as basal ${ }^{3} \mathrm{H}$-inositol phosphate release was unaffected by pretreatment with either TPA or mezerein. Moreover, the ability of a high concentration of calcium to activate phospholipase $\mathrm{C}$ directly and stimulate ${ }^{3} \mathrm{H}$-inositol phosphate release from digitonin-permeabilized SHSY5Y cells remained unchanged following chronic TPA or mezerein treatment, thus further reducing the likelihood of an inhibitory effect of the tumor promoters on phospholipase C itself.

Whereas morphological differentiation of SH-SY5Y cells resulted from pretreatment with TPA or mezerein, or removal of fetal calf serum, alterations in receptor number and in stimulated PPI turnover were observed only following pretreatment of the cells with the tumor promoters. These results suggest that differentiation of SH-SY5Y cells is not necessarily accompanied by changes in signal transduction events, and that the inhibitory effects of TPA and mezerein are likely to result from the direct activation of $\mathrm{PKC}$ and/or its subsequent down-regulation.

In summary, long-term exposure to TPA or mezerein resulted in a decline in muscarinic receptor-mediated PPI hydrolysis with a concomitant decrease in agonist-induced $\mathrm{Ca}^{2+}$ mobilization and PKC activity in human neuroblastoma SH-SY5Y cells. Our results indicate that the inhibitory effects produced by these agents are a consequence of a reduction in muscarinic receptor number as well as inhibition of $\mathrm{G}_{\mathrm{p}}$-stimulated PPI hydrolysis.

Acknowledgment: The authors wish to thank Dr. Anne Heacock for performing the sodium dodecyl sulfate-urea gel electrophoresis. This work was supported by NIMH Grant MH42652. C.L.C. is the recipient of a postdoctoral Training Grant, MH15794, from NIMH.

\section{REFERENCES}

Adem A., Mattsson M. E. K., Nordberg A., and Pahlman S. (1987) Muscarinic receptors in human SH-SY5Y neuroblastoma cell line: regulation by phorbol ester and retinoic acid-induced differentiation. Dev. Brain Res. 33, 235-242.

Akerman K. E. O., Scott I. G., and Anderson L. C. (1984) Functional differentiation of a human ganglion cell-derived neuroblastoma cell line SH-SY5Y induced by a phorbol ester (TPA). Neurochem. Int. 6, 77-80.

Ballester R. and Rosen O. M. (1985) Fate of immunoprecipitable protein kinase $\mathrm{C}$ in $\mathrm{GH}_{3}$ cells treated with phorbol 12-myristate 13-acetate. J. Biol. Chem. 260, 15194-15199.

Biedler J. L., Roffler-Tarlov S., Schachner M., and Freedman L. S. (1978) Multiple neurotransmitter synthesis by human neuroblastoma cell lines and clones. Cancer Res. 38, 3751-3757.

Blackshear P. J., Witters L. A., Girard P. R., Kuo J. F., and Quamo
S. N. (1985) Growth factor-stimulated protein phosphorylation in 3T3-L1 cells. $J$. Biol. Chem. 260, 13304-13315.

Cheng Y.-C. and Prusoff W. H. (1973) Relationship between the inhibition constant $\left(K_{\mathrm{i}}\right)$ and the concentration of inhibitor which causes 50 percent inhibition $\left(\mathrm{IC}_{50}\right)$ of an enzymatic reaction. Biochem. Pharmacol. 22, 3099-3108.

Cockcroft S. and Stutchfield J. (1988) Effect of pertussis toxin and neomycin on $G$ protein-stimulated polyphosphoinositide phosphodiesterase: a comparison between HL60 membranes and permeabilized cells. Biochem. J. 256, 343-350.

Fisher S. K. (1988) Recognition of muscarinic cholinergic receptors in human SK-N-SH neuroblastoma cells by quaternary and tertiary ligands is dependent upon temperature, cell integrity, and the presence of agonists. Mol. Pharmacol. 33, 414-422.

Fisher S. K. and Bartus R. T. (1985) Regional differences in the coupling of muscarinic receptors to inositol phospholipid hydrolysis in guinea pig brain. J. Neurochem. 45, 1085-1095.

Fisher S. K. and Heacock A. M. (1988) A putative $M_{3}$ muscarinic cholinergic receptor of high molecular weight couples to phosphoinositide hydrolysis in human SK-N-SH cells. $J$. Neurochem. 50, 984-987.

Fisher S. K. and Snider R. M. (1987) Differential receptor occupancy requirements for muscarinic cholinergic stimulation of inositol lipid hydrolysis in brain and in neuroblastomas. Mol. Pharmacol. 32, 81-90.

Fisher S. K., Domask L. M., and Roland R. (1989) Muscarinic receptor regulation of cytoplasmic $\mathrm{Ca}^{2+}$ concentrations in human SK-N-SH neuroblastoma cells: $\mathrm{Ca}^{2+}$ requirements for phospholipase C activation. Mol. Pharmacol. 35, 195-204.

Fowler C. J., Oneill C., Almqvist P., Nilsson S., Wiehagen B., and Winblad B. (1989) Muscarinic receptors coupled to inositol phospholipid breakdown in human SH-SY5Y neuroblastoma cells: effect of retinoic acid-induced differentiation. Neurochem. Int. 15, 73-79.

Geiger P. J. and Bessman S. P. (1972) Protein determination by Lowry's method in the presence of sulfhydryl reagents. Anal. Biochem. 49, 467-474.

Geny B., Stutchfield J., and Cockcroft S. (1989) Phorbol ester inhibits polyphosphoinositide phosphodiesterase activity stimulated by either $\mathrm{Ca}^{2+}$, fluoride, or GTP analogue in HL60 membranes and in permeabilized cells. Cell. Signal 1, 165-172.

Grynkiewicz G., Poenie M., and Tsien R. Y. (1985) A new generation of $\mathrm{Ca}^{2+}$ indicators with greatly improved fluorescence properties. J. Biol. Chem. 260, 3440-3450.

Heikkila J. E., Scott I. G., Suominen L. A., and Akerman K. E. O. (1987) Differentiation-associated decrease in muscarinic receptor sensitivity in human neuroblastoma cells. J. Cell. Physiol. 130, 157-162.

Hepler J. R., Earp H. S., and Harden T. K. (1988) Long-term phorbol ester treatment down-regulates protein kinase $\mathrm{C}$ and sensitizes the phosphoinositide signaling pathway to hormone and growth factor stimulation. J. Biol. Chem. 263, 7610-7619.

Honegger P. and Richelson E. (1976) Biochemical differentiation of mechanically dissociated mammalian brain in aggregating cell culture. Brain Res. 109, 335-354.

Katada T., Gilman A. G., Watanabe Y., Bauer S., and Jakobs K. H. (1985) Protein kinase $\mathrm{C}$ phosphorylates the inhibitory guanine nucleotide binding regulatory component and apparently suppresses its function in hormonal inhibition of adenylate cyclase. Eur. J. Biochem. 151, 431-437.

Lambert D. G., Ghataorre A. S., and Nahorski S. R. (1989) Muscarinic receptor binding characteristics of a human neuroblastoma SKN-SH and its clones SH-SY5Y and SH-EP1. Eur. J. Pharmacol. $165,71-77$.

Liles W. C., Hunter D. D., Meier K. E., and Nathanson N. W. (1986) Activation of protein kinase $C$ induces rapid internalization and subsequent degradation of muscarinic acetylcholine receptors in neuroblastoma cells. $J$. Biol. Chem. 261, 5307-5313.

Miyake R., Tanaka Y., Tsuda T., Kaibuchi K., Kikkawa U., and Nishizuka Y. (1984) Activation of protein kinase $C$ by nonphorbol tumor promoter, mezerein. Biochem. Biophys. Res. Commun. 121, 649-656. 
Munson P. J. and Rodbard D. (1980) LIGAND: a versatile computerized approach for characterization of ligand-binding systems. Anal. Biochem. 107, 220-239.

Nishizuka Y. (1984) The role of protein kinase C in cell surface signal transduction and tumour promotion. Nature 308, 693-698.

Orellana S., Solski P. A., and Brown J. H. (1987) Guanosine 5'-O(thiotriphosphate)-dependent inositol triphosphate formation in membranes is inhibited by phorbol ester and protein kinase $C$ J. Biol. Chem. 262, 1638-1643.

Pahlman S., Odelstad L., Larsson E., Grotte G., and Nilsson K. (1981) Phenotypic changes of human neuroblastoma cells in culture induced by $12-O$-tetradecanoylphorbol 13 -acetate. Int. J. Cancer 28, 583-589.

Pahlman S., Ruusala A.-I., Abrahamsson L., Mattsson M. E. K., and Esscher T. (1984) Retinoic acid-induced differentiation of cultured human neuroblastoma cells: a comparison with phorbol ester-induced differentiation. Cell Differ. 14, 135-144.

Pearce B., Morrow C., and Murphy S. (1988) Characteristics of phor- bol ester- and agonist-induced down-regulation of astrocyte receptors coupled to inositol phospholipid metabolism. J. Nettrochem. 50, 936-944.

Rhee S. G., Suh P.-G., Ryu S.-H., and Lee S. Y. (1989) Studies of inositol phospholipid-specific phospholipase C. Science 244, 546550.

Scatchard G. (1949) The attractions of proteins for small molecules and ions. Ann. NY Acad. Sci. 51, 660-672.

Serra M., Mei L., Roeske W. R., Lui G. K., Watson M., and Yamamura H. I. (1988) The intact neuroblastoma cell (SH-SY5Y) exhibits high-affinity $\left.{ }^{3} \mathrm{H}\right]$ pirenzepine binding associated with hydrolysis of phosphatidylinositols. J. Neurochem. 50, 15131521.

Snider R. M., Fisher S. K., and Agranoff B. W. (1987) Inositidelinked second messengers in the central nervous system, in Psychopharmacology: The Third Generation of Progress (Meltzer H. Y., ed), pp. 317-324. Raven Press, New York. 